\title{
BROOKHFVEN
}

NATIONAL LABORATORY

BNL-114552-2017-JA

\section{Tuning Li-ion Diffusion in a-LiMn1-xFexJ'04 Nanocrystals by Antisite Defects and Embedded P-phase for Advanced Li-ion Batteries}

\author{
J. Hu, W. Zhang
}

Submitted to Nano Letters

August 2017

Sustainable Energy Technologies Department

Brookhaven National Laboratory

\section{U.S. Department of Energy \\ USDOE Office of Energy Efficiency and Renewable Energy (EERE), Vehicle Technologies Office (EE-3V)}




\section{DISCLAIMER}

This report was prepared as an account of work sponsored by an agency of the United States Government. Neither the United States Government nor any agency thereof, nor any of their employees, nor any of their contractors, subcontractors, or their employees, makes any warranty, express or implied, or assumes any legal liability or responsibility for the accuracy, completeness, or any third party's use or the results of such use of any information, apparatus, product, or process disclosed, or represents that its use would not infringe privately owned rights. Reference herein to any specific commercial product, process, or service by trade name, trademark, manufacturer, or otherwise, does not necessarily constitute or imply its endorsement, recommendation, or favoring by the United States Government or any agency thereof or its contractors or subcontractors. The views and opinions of authors expressed herein do not necessarily state or reflect those of the United States Government or any agency thereof. 


\section{Tuning Li-ion diffusion in $\alpha-\mathrm{LiMn}_{1-\mathrm{x}} \mathrm{Fe}_{\mathrm{x}} \mathrm{PO}_{4}$ nanocrystals by antisite defects and embedded $\beta$-phase for advanced Li-ion batteries}

Jiangtao Hu, ${ }^{\dagger}$ Yinguo Xiao, ${ }^{\S}$ Hanting Tang, ${ }^{\dagger}$ HongBin Wang, ${ }^{\dagger}$ Ziqi Wang, ${ }^{\dagger}$ Chaokun Liu, ${ }^{\dagger}$ Hua Zeng, ${ }^{\dagger}$ Qingzhen

$$
\text { Huang, }{ }^{\mid l} \text { Yang Ren, }{ }^{\perp} \text { Chongmin Wang, },{ }^{\sharp} \text { Wei Zhang, }{ }^{*,+} \text { and Feng Pan }{ }^{*}, \dagger
$$

†School of Advanced Materials, Peking University, Shenzhen Graduate School, Shenzhen 518055, People's Republic

$$
\text { of China. }
$$

† Sustainable Energy Technologies Department, Brookhaven National Laboratory, Upton, NY 11973, USA

§Jülich Centre for Neutron Science and Peter Grünberg Institut, JARA-FIT, Forschungszentrum Jülich GmbH, 52425

$$
\text { Jülich, Germany }
$$

"NIST Center for Neutron Research, 100 Bureau Drive, National Institute of Standards and Technology, Gaithersburg, MD 20899, United States

${ }^{\perp}$ Electrochemical Technology Program, Chemical Sciences and Engineering Division, Argonne National Laboratory, Argonne, Illinois 60439, United States

\#Environmental Molecular Sciences Laboratory, Pacific Northwest National Laboratory, 902 Battelle Boulevard, Richland, Washington 99352, United States

*Corresponding author: panfeng@pkusz.edu.cn (F. P.), zhangw@bnl.gov (W. Z.)

Abstract. Olivine-structured $\mathrm{LiMn}_{1-\mathrm{x}} \mathrm{Fe}_{\mathrm{X}} \mathrm{PO}_{4}$ has become a promising candidate for cathode materials owing to its higher working voltage of $4.1 \mathrm{~V}$, and thus larger energy density than that of $\mathrm{LiFePO}_{4}$, which has been used for electric vehicles batteries with the advantage of high safety but disadvantage of low energy density due to its lower working voltage of $3.4 \mathrm{~V}$. One drawback of $\mathrm{LiMn}_{1-\mathrm{x}} \mathrm{Fe}_{\mathrm{x}} \mathrm{PO}_{4}$ electrode is its relatively low electronic and Li-ionic conductivity with Li-ion $1 \mathrm{D}$ diffusion. Herein, olivine-structured $\alpha$-LiMn ${ }_{0.5} \mathrm{Fe}_{0.5} \mathrm{PO}_{4}$ nanocrystals were synthesized with optimized Li-ion diffusion channels in $\mathrm{LiMn}_{1-x} \mathrm{Fe}_{\mathrm{x}} \mathrm{PO}_{4}$ nanocrystals by 
inducing high concentrations of $\mathrm{Fe}^{2+}-\mathrm{Li}^{+}$antisite defects, which showed impressive capacity improvements of approaching $162,127,73$ and $55 \mathrm{mAh} \mathrm{g}^{-1}$ at $0.1 \mathrm{C}, 10 \mathrm{C}, 50 \mathrm{C}$ and $100 \mathrm{C}$, respectively, and a long-term cycling stability of maintaining about $74 \%$ capacity after 1000 cycles at $10 \mathrm{C}$. By using high-resolution transmission electron microscopy imaging and joint refinement of hard X-ray and neutron powder diffraction patterns, we revealed that the extraordinary high-rate performance could be achieved by suppressing the formation of electrochemically inactive phase $\left(\beta-\mathrm{LiMn}_{1-x} \mathrm{Fe}_{x} \mathrm{PO}_{4}\right.$, which is firstly reported in this work) embedded in $\alpha$ - $\mathrm{LiMn}_{0.5} \mathrm{Fe}_{0.5} \mathrm{PO}_{4}$. Owing to the coherent orientation relationship between $\beta$ and $\alpha$ phases, the $\beta$ phase embedded would impede the $\mathrm{Li}^{+}$diffusion along the [100] and/or [001] directions which was activated by the high density of $\mathrm{Fe}^{2+}-\mathrm{Li}^{+}$antisite (4.24\%) in $\alpha$ phase. Thus, by optimizing concentrations of $\mathrm{Fe}^{2+}-\mathrm{Li}^{+}$antisite defects and suppressing $\beta$-phase-embedded olivine structure, Li-ion diffusion properties in $\mathrm{LiMn}_{1-\mathrm{x}} \mathrm{Fe}_{x} \mathrm{PO}_{4}$ nanocrystals can be tuned by generating new $\mathrm{Li}^{+}$tunneling. These findings may provide insights into the design and generation of other advanced electrode materials with improved rate performance.

Keywords: $\mathrm{LiMn}_{1-x} \mathrm{Fe}_{x} \mathrm{PO}_{4}$, high-rate capabilities, $\mathrm{Fe}^{2+}-\mathrm{Li}^{+}$antisite, $\beta$-LiMn ${ }_{1-x} \mathrm{Fe}_{x} \mathrm{PO}_{4}$, Lithium-ion battery

\section{Introduction}

Lithium ion batteries (LIB) have become an effective energy storage system which have been widely used for transportation applications, including hybrid electric vehicles (HEV), plug-in hybrid electric vehicles (PHEV), and electric vehicles (EV). ${ }^{1-3}$ However, the current commercial cathodes fall short of satisfying the needs for high energy density, acceptable rate capability and excellent stability through rapid (dis)charge

over thousands of cycles. For example, the wide application of $\mathrm{LiNi}_{\mathrm{x}} \mathrm{Co}_{\mathrm{y}} \mathrm{Mn}_{\mathrm{z}} \mathrm{O}_{2}$ is limited by its harsh synthesized conditions, security issues, and short working life, ${ }^{3-5}$ spinel $\mathrm{LiMn}_{2} \mathrm{O}_{4}$ suffers from severe capacity fade during electrochemical cycles, ${ }^{6,7}$ and olivine-structured $\mathrm{LiFePO}_{4}$ also possesses low energy density due to its lower working voltage of $3.4 \mathrm{~V} .{ }^{8}$ Recently, olivine-structured $\alpha$ - $\mathrm{LiMn}_{1-\mathrm{x}} \mathrm{Fe}_{\mathrm{x}} \mathrm{PO}_{4}$ has become a promising candidate for cathode materials owing to its higher working voltage of $4.1 \mathrm{~V}$, and thus larger 
energy density than that of $\mathrm{LiFePO}_{4}$ by doping manganese into $\mathrm{LiFePO}_{4}{ }^{9}, 10$ One drawback of $\alpha$ - $\mathrm{LiMn}_{1-\mathrm{x}} \mathrm{Fe}_{\mathrm{x}} \mathrm{PO}_{4}$ electrode is its relatively low electronic and Li-ionic conductivity, ${ }^{11,}{ }^{12}$ which has been effectively improved by several methods, such as carbon coating to enhance electronic conduction and nanosized active particles of electrodes with shortened Li-ionic diffusion length to enhance Li-ionic conduction. ${ }^{13-15}$ However, both experimental and theoretical studies claimed that the dynamic process of local Li-ionic diffusion could be tuned by structural defects, such as anti-site occupancies and substitutions being common in the nanosized electrodes materials. ${ }^{16-19}$. Therefore, we believe that, in order to ensure the efficient application of olivine-structured $\mathrm{LiMn}_{1-x} \mathrm{Fe}_{x} \mathrm{PO}_{4}$ in $\mathrm{LIB}$, electrochemical performance of the electrodes could be further enhanced while the fundamental knowledge of underlying Li-ionic transport processes vs. defects is revealed.

Many studies have been dedicated to investigate the electrochemical performance of two polymorphs of $\mathrm{LiFePO}_{4}$, i.e. $\alpha$ - and $\beta$ - $\mathrm{LiFePO}_{4}{ }^{20,21}$ Comparing to the $\alpha$ phase, the $\beta$ phase has been proved to possess almost no electrochemical activation, ${ }^{21,22}$ owing to Li-ions kept in captivity to pass the high energy barrier for $\mathrm{Li}$-ion transport through $\left[\mathrm{PO}_{4}\right]$ tetrahedra and $\left[\mathrm{FeO}_{6}\right]$ octahedra. ${ }^{23}$ In our previous work, $\beta-\mathrm{LiFePO}_{4}$ was actived by generating various defects to make new Li-ionic diffusion paths with the low energy barriers, however, electrochemical performance of the actived $\beta-\mathrm{LiFePO}_{4}$ is still not as good as that of $\alpha-\mathrm{LiFePO}_{4}{ }^{20}$ Therefore, the appearance of $\beta$ phase usually leads to the performance degradation, and the $\alpha$ phase has become the main candidate for the applications. In $\alpha$ - $\mathrm{LiMn}_{1-\mathrm{x}} \mathrm{Fe}_{\mathrm{x}} \mathrm{PO}_{4}$ materials, the Li-ion transport properties can be altered by the $\mathrm{Fe}^{2+}-\mathrm{Li}^{+}$antisite defects where $\mathrm{Fe}^{2+}$ ions reside inside the $\mathrm{Li}^{+}$diffusion channels along the [010] direction. The formation of antisite defects has been reported by X-ray diffraction and transmission electron microscopy (TEM) measurements in $\alpha$ - $\mathrm{LiMn}_{1-\mathrm{x}} \mathrm{Fe}_{\mathrm{x}} \mathrm{PO}_{4},{ }^{24,}{ }^{25}$ which would impede the $\mathrm{Li}^{+}$transport along the diffusion channels. ${ }^{26}$ On the other hand, it has been predicted by theoretical calculations that the anitsite defects with a high concentration $(>2 \%)$ will allow the Li-ion diffusion crossover the $1 \mathrm{D}$ diffusion channels and tend to shift the $1 \mathrm{D}$ to $2 \mathrm{D}$ and/or $3 \mathrm{D}$ diffusion. ${ }^{16,26-28}$ A number of 
experimental studies also demonstrated that electronic and Li-ionic conductivities are essentially two-dimensional in $\mathrm{LiFePO}_{4}$ single crystals, owing to the presence of antisite defects. ${ }^{29,}{ }^{30}$ Moreover, it is believed that the formation of antisite defects would enhance the rate capabilities by changing the two-phase to single-phase solid solution reaction in olivine-type electrodes. ${ }^{5,28}$

In this work, we induced high antisite defect concentrations of $5.27 \%$ and $4.24 \%$ into two kinds (named as $1 \#$ and $2 \#$ samples) of carbon-coated $\alpha$-LiMn ${ }_{0.5} \mathrm{Fe}_{0.5} \mathrm{PO}_{4}$ nanoparticles, respectively, which would activate new $\mathrm{Li}^{+}$tunneling in both of them. Crucial to this study is the suppression of forming electrochemically inactive $\beta$ - $\mathrm{LiMn}_{1-\mathrm{x}} \mathrm{Fe}_{\mathrm{x}} \mathrm{PO}_{4}$ nanodomains with size less than $10 \mathrm{~nm}$ inside the $100 \mathrm{~nm}$-sized $\alpha-\mathrm{LiMn}_{1-\mathrm{x}} \mathrm{Fe}_{x} \mathrm{PO}_{4}$ nanocrystals in the $1 \#$ electrode, but embedded in the $2 \#$ electrode, which blocks the Li-ion transport along the [100] and [001] directions, and thus causes the poor electrochemical performance in the 2\# electrode. The specific capacities of the superior $1 \# \mathrm{LiMn}_{0.5} \mathrm{Fe}_{0.5} \mathrm{PO}_{4} @ \mathrm{C}$ are 162,127, 73 and $55 \mathrm{mAh} \mathrm{g}^{-1}$ at $0.1 \mathrm{C}, 10 \mathrm{C}$, $50 \mathrm{C}$ and $100 \mathrm{C}$, respectively, which are higher than that of the 2\# $\mathrm{LiMn}_{0.5} \mathrm{Fe}_{0.5} \mathrm{PO}_{4} @ \mathrm{C}$ (over three times lower than that of $1 \#$ sample $\left(15.8 \mathrm{mAh} \mathrm{g}^{-1}\right)$ at $\left.100 \mathrm{C}\right)$. The $1 \#$ electrode also displays excellent cycling lifetime, i.e. sustaining about $74 \%$ of the total capacity during 1000 cycles at $10 \mathrm{C}$. Our findings revealed the importance of suppressing the $\beta$-phase formation to be embedded in $\alpha$-phase that is responsible for the enhanced rate capabilities and extended cycling lifetime in olivine-type electrodes, which may shed light on the design of novel materials with desired performance.

\section{Experimental Methods}

Synthesis of $\mathrm{LiFe}_{0.5} \mathrm{Mn}_{0.5} \mathrm{PO}_{4} @ \mathrm{C}$ : Two kinds of $\mathrm{LiMn}_{0.5} \mathrm{Fe}_{0.5} \mathrm{PO}_{4} @ \mathrm{C}$ materials were prepared using the same starting materials but different methods, which were named as $1 \# \mathrm{LiMn}_{0.5} \mathrm{Fe}_{0.5} \mathrm{PO}_{4} @ \mathrm{C}$ and 2\# $\mathrm{LiMn}_{0.5} \mathrm{Fe}_{0.5} \mathrm{PO}_{4} @ \mathrm{C}$, respectively. In the typical route, $\mathrm{FeSO}_{4} \cdot 7 \mathrm{H}_{2} \mathrm{O}(\mathrm{AR}, 99 \%), \mathrm{MnSO}_{4}(\mathrm{AR}, 99 \%), \mathrm{H}_{3} \mathrm{PO}_{4}$ (AR, $85 \%$ solution), and $\mathrm{LiOH} \cdot \mathrm{H}_{2} \mathrm{O}(\mathrm{AR}, 85 \%$ solution) were used as starting materials in a molar ratio of 0.5:0.5:1.275:2.7, and ethylene glycol (EG) was applied as solvent. The synthesis process took place under nitrogen atmosphere. For the synthesis of both $1 \#$ and $2 \# \mathrm{LiMn}_{0.5} \mathrm{Fe}_{0.5} \mathrm{PO}_{4} @ \mathrm{C}, 270 \mathrm{mmol} \mathrm{LiOH} \cdot \mathrm{H}_{2} \mathrm{O}$ was 
dissolved in $111 \mathrm{ml} \mathrm{EG}$ under ultrasonic apparatus to obtain $\mathrm{LiOH}$ solution. $50 \mathrm{mmol} \mathrm{FeSO}_{4} \cdot 7 \mathrm{H}_{2} \mathrm{O}, 50$ mmol $\mathrm{MnSO}_{4}$ and $0.5 \mathrm{mmol}$ ascorbic acid (as reducing agent to prevent the oxidation process of ferrous) were dissolved in $88 \mathrm{ml}$ EG to obtain $\mathrm{FeSO}_{4}$ and $\mathrm{MnSO}_{4}$ solution. Before $\mathrm{EG}$ was added, $\mathrm{MnSO}_{4}$ was dissolved in $3 \mathrm{ml}$ deionized water due to its poor solubility in EG. $150 \mathrm{mmol} \mathrm{H}_{3} \mathrm{PO}_{4}$ was dissolved in $22 \mathrm{ml}$ EG to obtain $\mathrm{H}_{3} \mathrm{PO}_{4}$ solution. Differently, for $2 \# \mathrm{LiMn}_{0.5} \mathrm{Fe}_{0.5} \mathrm{PO}_{4} @ \mathrm{C}, \mathrm{H}_{3} \mathrm{PO}_{4}$ solution was slowly added into $\mathrm{LiOH}$ solution under magnetic stirring. 5 minutes later, $\mathrm{FeSO}_{4}$ and $\mathrm{MnSO}_{4}$ solution was slowly added into the mixed solution. For $1 \# \mathrm{LiMn}_{0.5} \mathrm{Fe}_{0.5} \mathrm{PO}_{4} @ \mathrm{C}, \mathrm{H}_{3} \mathrm{PO}_{4}$ solution was slowly added into $\mathrm{FeSO}_{4}$ and $\mathrm{MnSO}_{4}$ solution under magnetic stirring. 5 minutes later, $\mathrm{LiOH}$ solution was slowly added into the mixed solution. Then the same procedure was followed for both samples. After stirring for 10 minutes, the mixture was healed up to $180{ }^{\circ} \mathrm{C}$ for 5 hours, and then cooled down to room temperature. The obtained precipitates were washed with deionized water and ethanol and dried in a vacuum drying oven at $70{ }^{\circ} \mathrm{C}$ for $6 \mathrm{~h}$. Then the LiMn $0.5 \mathrm{Fe}_{0.5} \mathrm{PO}_{4}$ materials were collected. To achieve carbon coating, LiMn ${ }_{0.5} \mathrm{Fe}_{0.5} \mathrm{PO}_{4}$ materials were mixed with $1.5 \mathrm{wt} \%$ of ascorbic acid and $18.5 \mathrm{wt} \%$ of glucose dissolved in deionized water and ethanol. After grinding for 30 minutes, the mixture was heated at $650{ }^{\circ} \mathrm{C}$ for 6 hours in Ar atmosphere.

Characterization: Two kinds The crystallographic structures of $1 \#$ and $2 \# \mathrm{LiMn}_{0.5} \mathrm{Fe}_{0.5} \mathrm{PO}_{4}$ were detected by using Bruker D8 Advance diffractometer with $\mathrm{Cu} \mathrm{K \alpha}(\lambda=0.15418 \mathrm{~nm})$ in the range of $10-120^{\circ}$ at speed of $0.02^{\circ} \mathrm{s}^{-1}$. The morphologies of the materials were measured on ZEISS Supra-55 scanning electron microscope. The neutron powder diffraction data were collected on the two materials using the BT-1 high-resolution powder diffractometer at the NIST Center for Neutron Research. The high-energy x-ray (hard X-ray) wavelength is $0.011725 \mathrm{~nm}$ and the 2D detector is a Perkin-Elmer amorphous silicon flat panel detector. We took joint refinement method and used Fullprof Suite Toolbar to simulate the neutron powder diffraction data and hard X-rays data at the same time. The high-resolution transmission electron microscopy images and electron diffraction patterns of $1 \#$ and $2 \# \mathrm{LiMn}_{0.5} \mathrm{Fe}_{0.5} \mathrm{PO}_{4}$ were obtained by using a transmission electron microscopy (JEM-3200FS, JEOL) at an acceleration voltage of $300 \mathrm{kV}$. Fourier 
transform infrared spectrometer (FTIR) spectrums were tested by a PerkinElmer FT-IR spectrometer.

Electrochemical testing: A coin cell type CR2032 was used for electrochemical test. $\mathrm{LiMn}_{0.5} \mathrm{Fe}_{0.5} \mathrm{PO}_{4} @ \mathrm{C}$, $\mathrm{XC}-72$ and polyvinylidene fluoride (PVDF) were mixed with weight ratio of 5:3:2. The composite was dissolved in N-Methylpyrrolidone (NMP) to form electrode slurry. The slurry was coated on aluminum and cut into sequin as working electrode. Lithium metal was used as the counter electrode, and $1 \mathrm{M} \mathrm{LiPF}_{6}$ in a mixture of ethylene chloride (EC), diethyl chloride (DEC), and dimethyl chloride (DMC) was used as an electrolyte with a volume ratio of 1:1:1. All the cells were assembled in a glove box with water/oxygen content lower than $1 \mathrm{ppm}$ and tested at room temperature. We also packaged the coin cell with conductive black and reduced the content to be $10 \%$, and the percentages of the final samples and PVDF in the working electrodes were $80 \%$ and $10 \%$, respectively. The rate performance of XC-72 was also measured between $2.0 \mathrm{~V}$ and $4.5 \mathrm{~V}$, and the working electrodes were composed of $80 \% \mathrm{XC}-72$ and $20 \% \mathrm{PVDF}$. The electrochemical data were collected between 2.0 and $4.5 \mathrm{~V}$ at different C-rates. The cyclic voltammetry (CV) results were recorded by a CHI electrochemical workstation (CHI604E).

\section{Result and Discussion}

The 1\# and 2\# LiMn $0.5 \mathrm{Fe}_{0.5} \mathrm{PO}_{4} @ \mathrm{C}$ samples, which are synthsized by two different methods (see the Experimental Section for detailed information), possess different morphologies and electrochemical performance, especially different capacities at high current densities. X-ray diffraction (XRD) patterns of 1\# and 2\# LiMn $0.5 \mathrm{Fe}_{0.5} \mathrm{PO}_{4} @ \mathrm{C}$ are shown in Figure 1a, demonstrating the formation of olivine-structured $\alpha-\mathrm{LiMn}_{0.5} \mathrm{Fe}_{0.5} \mathrm{PO}_{4}$ in both of these two samples. The particle size of $\alpha$-LiMn $0.5 \mathrm{Fe}_{0.5} \mathrm{PO}_{4}$ in sample $2 \#$ is only

a little larger than that in sample 1\#, as illustrated by SEM and TEM images in Figure 1b, 1c and S1. We also performed Maud refinement on the XRD patterns of the two materials, which shows that the averaged particle sizes of $1 \#$ and $2 \#$ are $53 \mathrm{~nm}$ and $61 \mathrm{~nm}$, respectively (Figure S2). Figure $\mathbf{S 3}$ shows that the specific capacity of $1 \# \mathrm{LiMn}_{0.5} \mathrm{Fe}_{0.5} \mathrm{PO}_{4} @ \mathrm{C}\left(162 \mathrm{mAh} \mathrm{g}^{-1}\right)$ is a little larger than that of $2 \# \mathrm{LiMn}_{0.5} \mathrm{Fe}_{0.5} \mathrm{PO}_{4} @ \mathrm{C}(155$ $\left.\mathrm{mAh} \mathrm{g}^{-1}\right)$, when the electrodes were cycled between $2.0 \mathrm{~V}$ and $4.5 \mathrm{~V}\left(\mathrm{vs} . \mathrm{Li}^{2} / \mathrm{Li}^{+}\right)$at $0.1 \mathrm{C}$. However, such 
difference between capacities becomes more and more significant when the cycling rate is increased up to $100 \mathrm{C}$ (Figure 1d and S4). It is worth to note that the capacity of 1\# $\mathrm{LiMn}_{0.5} \mathrm{Fe}_{0.5} \mathrm{PO}_{4} @ \mathrm{C}\left(54.6 \mathrm{mAh} \mathrm{g}^{-1}\right)$ is over three times larger than that of $2 \#$ sample $\left(15.8 \mathrm{mAh} \mathrm{g}^{-1}\right)$ at $100 \mathrm{C}$. Such large disparity between capacities at high rates can still be detected, after using different amount of conductive carbon as shown in Figure S5. The different performance between these two samples is also evidenced by the cyclic voltammetry (CV) curves in Figure 1e. The CV curves of both electrodes possess two redox peaks at $\sim 3.5 \mathrm{~V}$ and $\sim 4.1 \mathrm{~V}$ vs. $\mathrm{Li} / \mathrm{Li}^{+}$, corresponding to the $\mathrm{Fe}^{3+} / \mathrm{Fe}^{2+}$ and $\mathrm{Mn}^{3+} / \mathrm{Mn}^{2+}$, respectively. However, when the scan speed increases from $20 \mathrm{mV} \mathrm{s}^{-1}$ to $100 \mathrm{mV} \mathrm{s}^{-1}$, the redox peak of $\mathrm{Mn}^{3+} / \mathrm{Mn}^{2+}$ becomes absent, which is caused by the polarization effect (Figure S6). The half-widths of the CV peaks of 2\# $\mathrm{LiMn}_{0.5} \mathrm{Fe}_{0.5} \mathrm{PO}_{4} @ \mathrm{C}$ are wider than that of $1 \# \mathrm{LiMn} 0.5 \mathrm{Fe}_{0.5} \mathrm{PO}_{4} @ \mathrm{C}$. The voltage differences between the $\mathrm{Fe}^{3+} / \mathrm{Fe}^{2+}$ and $\mathrm{Mn}^{3+} / \mathrm{Mn}^{2+}$ redox peaks of $2 \# \mathrm{LiMn}_{0.5} \mathrm{Fe}_{0.5} \mathrm{PO}_{4} @ \mathrm{C}$ are bigger than that of $1 \# \mathrm{LiMn}_{0.5} \mathrm{Fe}_{0.5} \mathrm{PO}_{4} @ \mathrm{C}$, which have been marked by blue and cyan colors in Figure 1e, respectively. All of these features indicate that the transmittability of Li-ions in sample $1 \#$ is higher than that in sample 2\#. Furthermore, both of the two materials demonstrate a long-term cycle stability at $10 \mathrm{C}$, because about $74 \%$ and $49 \%$ of total capacity were maintained after 1000 cycles at $10 \mathrm{C}$ in $1 \#$ and 2\# LiMn0.5 $\mathrm{Fe}_{0.5} \mathrm{PO}_{4} @ \mathrm{C}$ (Figure S7), respectively. Therefore, our 1\# LiMn $0.5 \mathrm{Fe}_{0.5} \mathrm{PO}_{4} @ \mathrm{C}$ nanoparticles display superior high-rate capability and long-term cycling stability, which have not been demonstrated in other $\mathrm{LiMn}_{0.5} \mathrm{Fe}_{0.5} \mathrm{PO}_{4}$-based materials reported in previous studies (Table S1). ${ }^{13,14,31-34}$

In order to understand the origin of the enhanced electrochemical performance in sample 1\#, the concentrations of antisite defects in both samples were accurately determined by jointly refining and simulating the neutron powder and hard X-ray diffraction patterns. Such analysis method allows us to take the advantages of both techniques at the same time, i.e. recognition on Fe/Mn by neutron diffraction and identifying precise lattice parameters by hard X-ray diffraction ${ }^{35,36}$. The refinement results are shown in Figure 2, Table S2 and S3. The concentrations of $\mathrm{Fe}^{2+}-\mathrm{Li}^{+}$antisite defects are $5.27 \%$ and $4.24 \%$ in $1 \#$ and 
2\# $\mathrm{LiMn}_{0.5} \mathrm{Fe}_{0.5} \mathrm{PO}_{4} @ \mathrm{C}$, respectively, which are higher than the value of $<2 \%$ in $\mathrm{LiMn}_{0.5} \mathrm{Fe}_{0.5} \mathrm{PO}_{4}$ estimated by atomistic modeling method. ${ }^{26}$ The Infrared Radiation (IR) result also confirmed that the defect concentration of $1 \# \mathrm{LiMn}_{0.5} \mathrm{Fe}_{0.5} \mathrm{PO}_{4} @ \mathrm{C}$ is higher than that of $2 \# \mathrm{LiMn}_{0.5} \mathrm{Fe}_{0.5} \mathrm{PO}_{4} @ \mathrm{C}$ (Figure S8). In order to verify whether the $\mathrm{Mn}^{2+}-\mathrm{Li}^{+}$antisite defects are formed in both samples, we fixed the occupation ratio of $\mathrm{Fe}$ and refined the sites of $\mathrm{Mn}$ and $\mathrm{Li}$ ions. The occupation ratios of $\mathrm{Li}, \mathrm{Fe}$ and $\mathrm{Mn}$ ions at $4 \mathrm{c}$ sites (the center of $\mathrm{FeO}_{6}$ or $\mathrm{MnO}_{6}$ octahedra) are $3.88 \%, 46.08 \%$ and $50.04 \%$ in sample 2, respectively, which indicates that the $\mathrm{Mn}^{2+}-\mathrm{Li}^{+}$antisite defect is nonexistent. A similar refinement result was also obtained in $1 \#$ $\mathrm{LiMn}_{0.5} \mathrm{Fe}_{0.5} \mathrm{PO}_{4} @ \mathrm{C}$. These results are similar as that reported in $\mathrm{LiFe}_{1-\mathrm{x}} \mathrm{Mn}_{\mathrm{x}} \mathrm{PO}_{4}$ samples, in which the $\mathrm{Mn}$ ions at $4 \mathrm{c}$ sites can be barely exchanged with $\mathrm{Li}$ ions, owing to the larger ionic radius of $\mathrm{Mn}^{2+}$ than that of $\mathrm{Fe}^{2+}$ and $\mathrm{Li}^{+} \cdot 37$

After identifying the structural differences through neutron and XRD diffractions at the electrode scale, the crystalline structures in the localized areas of these two materials were measured by using high-resolution transmission electron microscopy (HRTEM) imaging. A single nanoparticle of 2\# $\mathrm{LiMn}_{0.5} \mathrm{Fe}_{0.5} \mathrm{PO}_{4} @ \mathrm{C}$ sample, as shown in Figure 3a, was used to obtain the electron diffraction pattern (Figure 3b), in which the zone axis can be indexed to be the [010] direction of $\alpha$ - $\mathrm{LiMn}_{0.5} \mathrm{Fe}_{0.5} \mathrm{PO}_{4}$. However, the HRTEM images obtained from the local areas $\mathrm{c}$ and $\mathrm{d}$ in Figure 3a revealed the existence of different structures in $\alpha-\mathrm{LiMn}_{0.5} \mathrm{Fe}_{0.5} \mathrm{PO}_{4}$ (Figure 3c and 3d). In contrast to the olivine structure of $\alpha$-LiMn ${ }_{0.5} \mathrm{Fe}_{0.5} \mathrm{PO}_{4}$ in region $\mathrm{c}$, as evidenced by the HRTEM image in Figure 3c and the corresponding fast Fourier transform (FFT) pattern in Figure 3f, the HRTEM image (Figure 3d) and corresponding FFT pattern (Figure 3h) display a different structure of $\beta$ - $\mathrm{LiMn}_{1-\mathrm{x}} \mathrm{Fe}_{\mathrm{x}} \mathrm{PO}_{4}$ in the nearby local region $\mathrm{d}$ with a size of about $8 \mathrm{~nm}$. According to the FFT patterns in Figure $\mathbf{3} \mathbf{f}$ and $\mathbf{3 h}$, the crystalline orientation relationship between $\alpha$-LiMn ${ }_{0.5} \mathrm{Fe}_{0.5} \mathrm{PO}_{4}$ and $\beta$-LiMn ${ }_{1-x} \mathrm{Fe}_{x} \mathrm{PO}_{4}$ can be determined in the following: $[010]_{\alpha} / /[011]_{\beta},(100)_{\alpha} / /(100)_{\beta},(001)_{\alpha} / /(011)_{\beta}$. The lattice spacing of $(400)_{\alpha}$ and $(002)_{\alpha}$ planes match very well with that of $(200)_{\beta}$ and $(0-22)_{\beta}$, respectively, thus the $\alpha$ and $\beta$ phase cannot be distinguished in the electron diffraction pattern of the whole particle in Figure 
3b. It is worth to note that the theoretical misfit along the [100] direction between $\alpha$ and $\beta \mathrm{LiFePO}_{4}$ phases is about $7.4 \% .{ }^{21}$ However, substitution of Fe for Mn can alter the lattice spacing of both phases, ${ }^{37,38}$ which may minimize the disparity between the lattice spacing, and then allow the perfect match to occur. In addition, no peaks of $\beta$ phase were observed in the XRD pattern in Figure 1a, which may result from the inadequate amount of $\beta$ phase. Similar HRTEM measurements were also performed on single nanoparticles of 1\# LiMn ${ }_{0.5} \mathrm{Fe}_{0.5} \mathrm{PO}_{4} @ \mathrm{C}$ sample, but no $\beta$ phase was found in the local regions of the nanoparticles, as shown by the typical HRTEM images in Figure S9.

The results from multiple characterizations at both the electrode and single-particle scales imply that in both of the highly defective $1 \#$ and $2 \# \alpha$-LiMn $0.5 \mathrm{Fe}_{0.5} \mathrm{PO}_{4}$ materials, the $\beta$-LiMn ${ }_{1-x} \mathrm{Fe}_{x} \mathrm{PO}_{4}$ phase $(<10 \mathrm{~nm}$ nanodomains) was only embedded in $\alpha$ - $\mathrm{LiMn}_{0.5} \mathrm{Fe}_{0.5} \mathrm{PO}_{4}$ phase (about $100 \mathrm{~nm}$ nanocrystals) in sample 2\# which possesses worse electrochemical performance than that of sample $1 \#$. The different electrochemical performance of the two materials at high current density were briefly shown in Figure 4a. We proposed one possible mechanism of the Li-ion transport, phase morphology, and their correlation to the different electrochemical performance in these two $\alpha$ - $\mathrm{LiMn}_{0.5} \mathrm{Fe}_{0.5} \mathrm{PO}_{4}$ samples at the atomic scale. In a defect-free $\alpha$-LiMn $0.5 \mathrm{Fe}_{0.5} \mathrm{PO}_{4}$ nanoparticle, the Li-ion migrates preferentially along $1 \mathrm{D}$ channels, i.e. the [010] direction (Figure 4b). However, the concentrations of $\mathrm{Fe}^{2+}-\mathrm{Li}^{+}$antisite defects are high enough in both samples 1 and 2, thus they may generate new tunneling of $\mathrm{Li}^{+}$which are differernt from the $1 \mathrm{D}$ channels, allowing the Li-ion diffusion along [100] and/or [001] directions with considerable Li-ion diffusivity. ${ }^{16,29,30}$ The transport network made by the new tunneling may be associated with the solid-solution transformation with facile Li-ion migration at elevated rates, which leads to the superior high-rate capabilities in sample 1 (Figure 4d). We hypothesize that a similar electrochemical performance should have been detected in sample 2\#, owing the similar level of defect concentrations in these two samples. However, according to the HRTEM results in Figure 3, some $\beta$ - $\mathrm{LiMn}_{1-x} \mathrm{Fe}_{x} \mathrm{PO}_{4}$ nanodomains were formed in the matrix of $2 \# \alpha$ - $\mathrm{LiMn}_{0.5} \mathrm{Fe}_{0.5} \mathrm{PO}_{4}$, with the planes of $(100)_{\beta}$ and $(011)_{\beta}$ connecting very well with $(100)_{\alpha}$ and $(001)_{\alpha}$, respectively. Owing to the highly 
poor Li-ion diffusivity in $\beta$ phase, the formation of $\beta$ phase tends to block parts of Li-ion diffusion paths so as to slow down the Li-ion transport along the [100] and [001] directions in a whole particle of $2 \#$ $\alpha$-LiMn ${ }_{0.5} \mathrm{Fe}_{0.5} \mathrm{PO}_{4}$ (Figure 4c), as been evidenced by the large half-widths of $\mathrm{CV}$ peaks of sample 2 in Figure 1e. In addition, Li-ions diffuse inefficiently along [010] direction that are blocked by the antisite defects, which also leads to substantially low ionic transport, and then the degradation of high-rate performance in sample $2 \#$.

\section{Conclusions}

In summary, we synthesized and compared two kinds of olivine-structured $\alpha$-LilMn $0.5 \mathrm{Fe}_{0.5} \mathrm{PO}_{4}$ electrodes with different electrochemical performance and phase morphologies. Both of these two electrodes contain high concentrations of $\mathrm{Fe}^{2+}-\mathrm{Li}^{+}$antisite defects. These defects may be responsible for the activation of facile Li-ion transport via new tunneling at high rates. Crucially, by using a suitable synthesis route, $\beta$-LiMn ${ }_{1-x} \mathrm{Fe}_{x} \mathrm{PO}_{4}$ phase with poor Li-ion diffusivity was only suppressed in local regions of a single nanoparticle of the $1 \#$ electrode. Owing to the coherent orientation relationship between $\alpha$ and $\beta$ phases, the $\beta$ phase would effectively impede the Li-ion migration along the [100] and [001] directions. Therefore, high-rate capabilities were significantly enhanced in the $1 \#$ electrode, which cannot be achieved in the $2 \#$ electrode prepared by a different synthesis process. Together with the excellent high-rate capability, the $1 \#$ electrode shows superior long-term cycling stability compared to other $\mathrm{LiMn}_{0.5} \mathrm{Fe}_{0.5} \mathrm{PO}_{4}$-based electrodes. Our findings demonstrate the importance of controlling the formation of electrochemically inactive $\beta$ phase in olivine-based electrodes. Both the outstanding performance and the atomistic mechanisms of it may pave the way towards clarifying the requisite synthesis strategies for novel electrodes with optimized electrochemical performance.

\section{ASSOCIATED CONTENT}

\section{Supporting Information}


Materials characterization, electrochemical performance and crystallographic details of $1 \#$ and $2 \#$

LiMn $0.5 \mathrm{Fe}_{0.5} \mathrm{PO}_{4} @ \mathrm{C}$ are shown in the supporting information.

\section{Acknowledgements}

This work was financially supported by National Materials Genome Project (2016YFB0700600), the National Natural Science Foundation of China (No. 21603007 and 51672012), and Shenzhen Science and Technology Research Grant (No. JCYJ20150729111733470, JCYJ20151015162256516).

\section{Author Information}

Corresponding Author: panfeng@pkusz.edu.cn (F. P.), zhangw@bnl.gov (W. Z.)

\section{Notes}

The authors declare no competing financial interests.

\section{References}

1. Manthiram, A. J. Phys. Chem. Lett. 2011, 2, 176-184.

2. Kang, B.; Ceder, G. Nature 2009, 458, 190-193.

3. Whittingham, M. S. Chem. Rev. 2004, 104, 4271-4301.

4. Armstrong, A. R.; Bruce, P. G. Nature 1996, 381, 499-500.

5. Whittingham, M. S. Chem. Rev. 2014, 114, 11414-11443.

6. Jang, D. H.; Shin, Y. J.; Oh, S. M. J. Electrochem. Soc. 1996, 143, 2204-2211.

7. Choa, J. J. Electrochem. Soc. 1999, 146, 3577.

8. Yuan, L.-X.; Wang, Z.-H.; Zhang, W.-X.; Hu, X.-L.; Chen, J.-T.; Huang, Y.-H.; Goodenough, J. B. Energy Environ. Sci. 2011, 4, 269-284.

9. Ravnsbæk, D. B.; Xiang, K.; Xing, W.; Borkiewicz, O. J.; Wiaderek, K. M.; Gionet, P.; Chapman, K. W.; Chupas, P. J.; Tang, M.; Chiang, Y.-M. Nano Lett. 2016, 16, 2375-2380.

10. Hu, J.; Jiang, Y.; Cui, S.; Duan, Y.; Liu, T.; Guo, H.; Lin, L.; Lin, Y.; Zheng, J.; Amine, K.; Pan, F. Adv. Energ. Mater: 2016, $6,1600856$.

11. Sin, B. C.; Lee, S. U.; Jin, B.-S.; Kim, H.-S.; Kim, J. S.; Lee, S.-I.; Noh, J.; Lee, Y. Solid State Ionics 2014, $260,2-7$.

12. Ojczyk, W.; Marzec, J.; Dygas, J.; Krok, F.; Liu, R. S.; Molenda, J. Mater. Sci-Poland 2006, 24, $103-113$.

13. Yan, S.-Y.; Wang, C.-Y.; Gu, R.-M.; Li, M.-W. J. Solid State Electr: 2015, 19, 2943-2950.

14. Xiang, W.; Wu, Z.-G.; Wang, E.-H.; Chen, M.-Z.; Song, Y.; Zhang, J.-B.; Zhong, Y.-J.; Chou, S.-L.; Luo, J.-H.; Guo, X.-D. J. Power Sources 2016, 329, 94-103.

15. Martha, S. K.; Grinblat, J.; Haik, O.; Zinigrad, E.; Drezen, T.; Miners, J. H.; Exnar, I.; Kay, A.; Markovsky, B.; Aurbach, D. Angew. Chem. Int. Edit. 2009, 48, 8559-63.

16. Malik, R.; Burch, D.; Bazant, M.; Ceder, G. Nano Lett. 2010, 10, 4123-4127.

17. Morgan, D.; Van der Ven, A.; Ceder, G. Electrochem. Solid St. 2004, 7, A30-A32. 
18. Gibot, P.; Casas-Cabanas, M.; Laffont, L.; Levasseur, S.; Carlach, P.; Hamelet, S.; Tarascon, J. M.; Masquelier, C. Nat. Mater: 2008, 7, 741-747.

19. Omenya, F.; Chernova, N. A.; Zhang, R.; Fang, J.; Huang, Y.; Cohen, F.; Dobrzynski, N.; Senanayake, S.; Xu, W.; Whittingham, M. S. Chem. Mater: 2013, 25, 85-89.

20. Guo, H.; Song, X.; Zhuo, Z.; Hu, J.; Liu, T.; Duan, Y.; Zheng, J.; Chen, Z.; Yang, W.; Amine, K.; Pan, F. Nano Lett. 2016, 16, 601-608.

21. Garcı'a-Moreno, O.; M. Alvarez-Vega; García-Alvarado, F.; García-Jaca, J.; Gallardo-Amores, J. M.; Sanjuán, M. L.; Amador, U. Chem. Mater: 2001, 13, 1570-1576.

22. Assat, G.; Manthiram, A. Inorg. Chem. 2015, 54, 10015-10022.

23. Ashton, T. E.; Laveda, J. V.; MacLaren, D. A.; Baker, P. J.; Porch, A.; Jones, M. O.; Corr, S. A. J. Mater. Chem. A 2014, 2, 6238-6245.

24. Guo, X.; Wang, M.; Huang, X.; Zhao, P.; Liu, X.; Che, R. J. Mater: Chem. A 2013, 1, 8775-8781.

25. Jensen, K.; Christensen, M.; Tyrsted, C.; Brummerstedt Iversen, B. J. Appl. Crystallogr: 2011, 44, $287-294$.

26. Gardiner, G. R.; Islam, M. S. Chem. Mater: 2010, 22, 1242-1248.

27. Adams, S. J. Solid State Electr: 2010, 14, 1787-1792.

28. Malik, R.; Abdellahi, A.; Ceder, G. J. Electrochem. Soc. 2013, 160, A3179-A3197.

29. Amin, R.; Balaya, P.; Maier, J. Electrochem. Solid St. 2007, 10, A13-A16.

30. Malik, R.; Abdellahi, A.; Ceder, G. J. Electrochem. Soc. 2013, 160, A3179-A3197.

31. Chi, Z.-X.; Zhang, W.; Wang, X.-S.; Cheng, F.-Q.; Chen, J.-T.; Cao, A.-M.; Wan, L.-J. J. Mater: Chem. A 2014, 2, 17359-17365.

32. Shen, H.; Xiang, W.; Shi, X.; Zhong, B.; Liu, H. Ionics 2015, 22, 193-200.

33. Zhong, Y.-J.; Li, J.-T.; Wu, Z.-G.; Guo, X.-D.; Zhong, B.-H.; Sun, S.-G. J. Power Sources 2013, 234, $217-222$.

34. Xiang, W.; Zhong, Y. J.; Ji, J. Y.; Tang, Y.; Shen, H.; Guo, X. D.; Zhong, B. H.; Dou, S. X.; Zhang, Z. Y. Phys. Chem. Chem. Phys. 2015, 17, 18629-18637.

35. Wlodawer, A.; Sjolin, L. Biochemistry 1983, 22, 2720-2728.

36. Afonine, P. V.; Mustyakimov, M.; Grosse-Kunstleve, R. W.; Moriarty, N. W.; Langan, P.; Adams, P. D. Acta Crystallogr: D 2010, 66, 1153-1163.

37. Jensen, K. M. Ø.; Christensen, M.; Gunnlaugsson, H. P.; Lock, N.; Bøjesen, E. D.; Proffen, T.; Iversen, B. B. Chem. Mater: 2013, 25, 2282-2290.

38. Yamada, A.; Hosoya, M.; Chung, S.-C.; Kudo, Y.; Hinokuma, K.; Liu, K.-Y.; Nishi, Y. J. Power Sources 2003, 119-121, 232-238. 
Figures and Captions
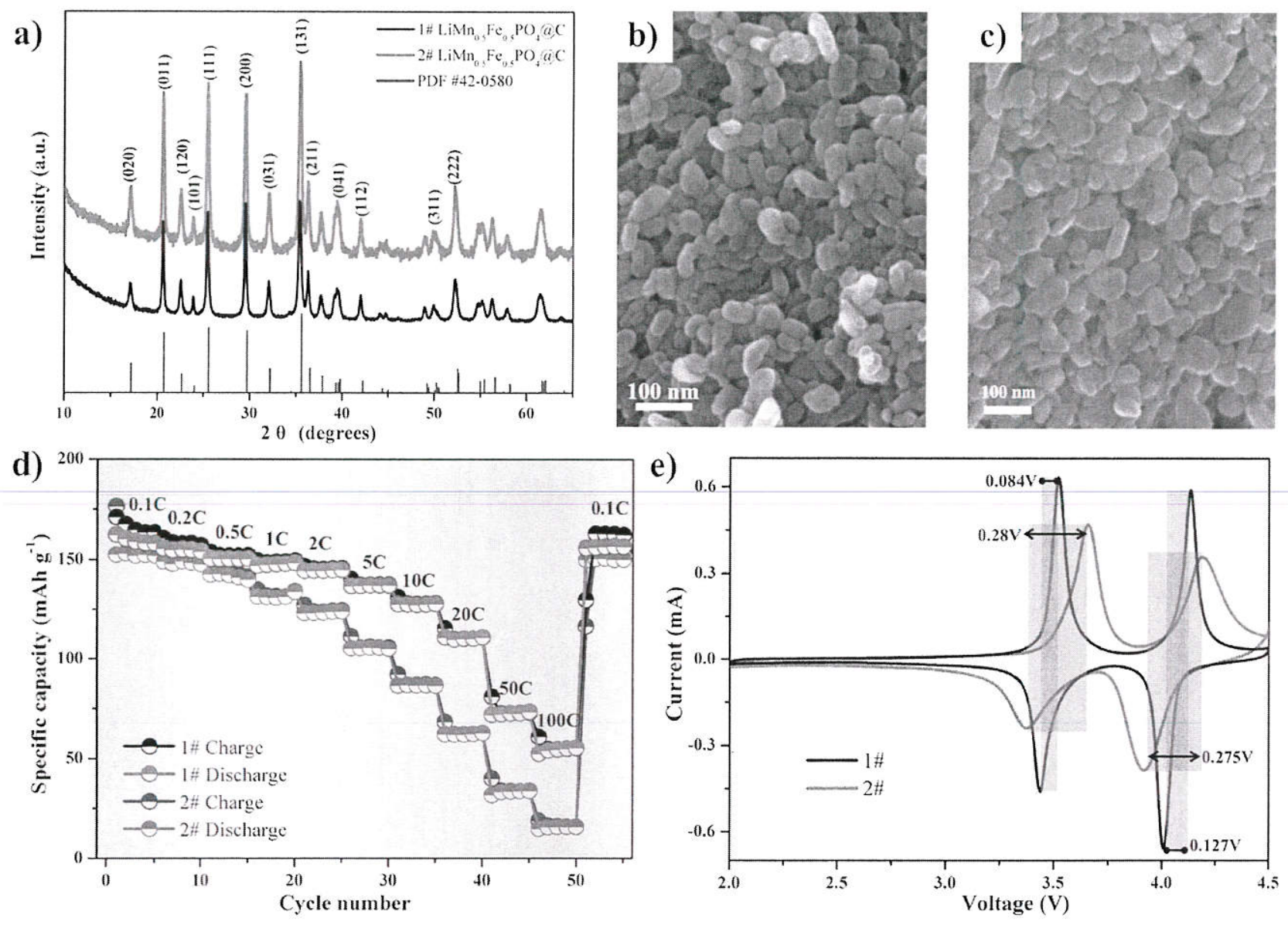

Figure 1. Crystalline structures and electrochemical performance of $1 \#$ and 2\# $\mathrm{LiMn}_{0.5} \mathrm{Fe}_{0.5} \mathrm{PO}_{4} @ \mathrm{C}$ electrodes. (a) XRD patterns of $1 \#$ and 2\# LiMn $0.5 \mathrm{Fe}_{0.5} \mathrm{PO}_{4} @ \mathrm{C}$ electrodes. (b, c) SEM images of $1 \#$ and 2\# LiMn $0.5 \mathrm{Fe}_{0.5} \mathrm{PO}_{4} @ \mathrm{C}$, respectively. (d) Different rate performance of $1 \#$ and 2\# $\mathrm{LiMn}_{0.5} \mathrm{Fe}_{0.5} \mathrm{PO}_{4} @ \mathrm{C}$ electrodes at rates from $0.1 \mathrm{C}$ to $100 \mathrm{C}$, showing the increasing disparity between capacities at elevated rates Both electrodes were cycled between $2.0 \mathrm{~V}$ and $4.5 \mathrm{~V}$. (e) CV curves of 1\# and 2\# $\mathrm{LiMn}_{0.5} \mathrm{Fe}_{0.5} \mathrm{PO}_{4} @ \mathrm{C}$ under the same scanning rate of $0.2 \mathrm{mV} \mathrm{s}^{-1}$. The small and large half-widths of the CV peaks in $1 \#$ and $2 \#$ electrodes are marked by cyan and blue colors, respectively. 

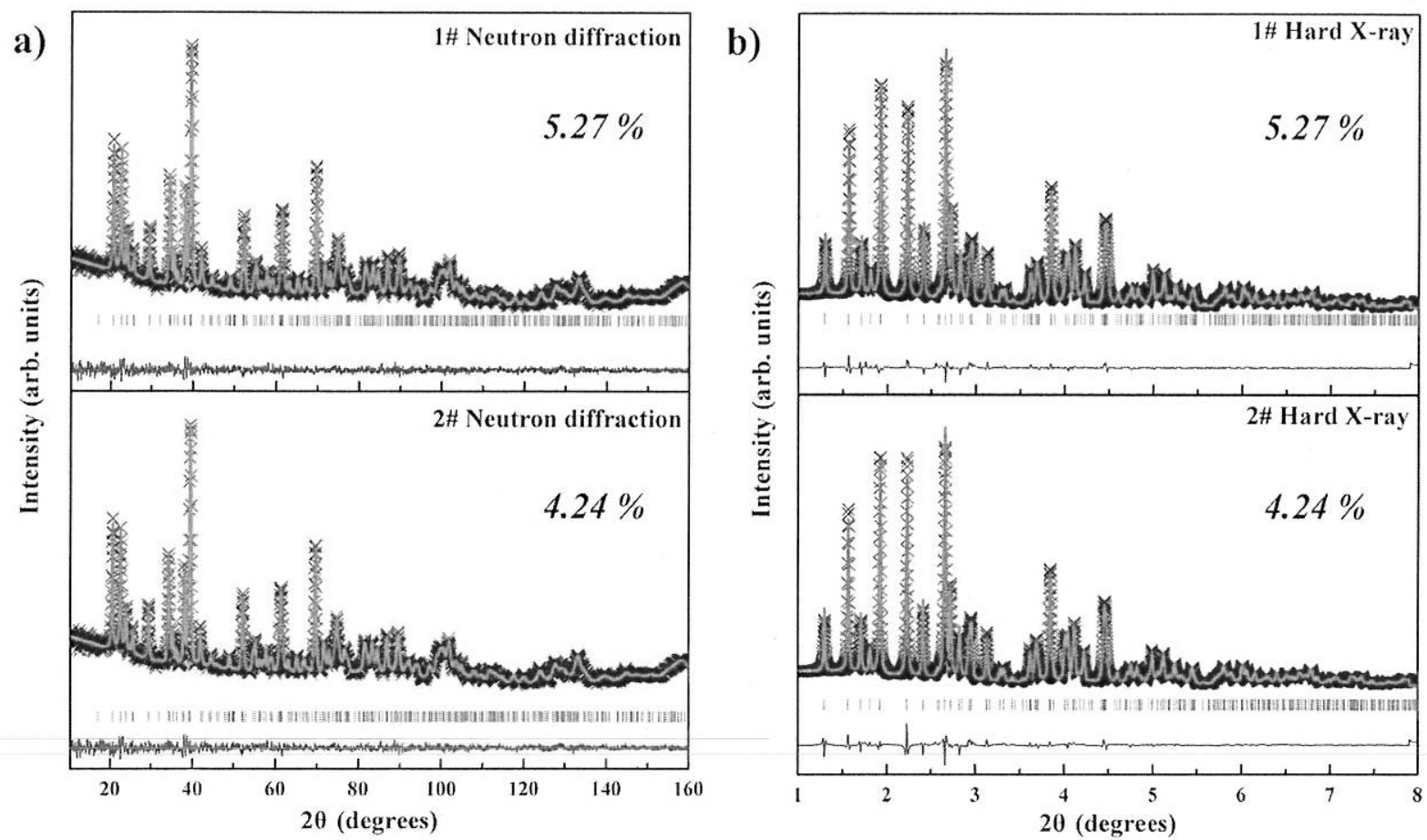

Figure 2. High concentrations of $\mathrm{Fe}^{2+}-\mathrm{Li}^{+}$antisite defects in $1 \#$ and $2 \# \mathrm{LiMn}_{0.5} \mathrm{Fe}_{0.5} \mathrm{PO}_{4} @ \mathrm{C}$ electrodes (inserted in the plots), as determined by joint Rietveld refinement of (a) neutron powder and (b) hard X-ray diffraction patterns, with black crosses for the experimental data points, red lines for fitted profiles, blue lines for difference and green bars for Bragg positions. 

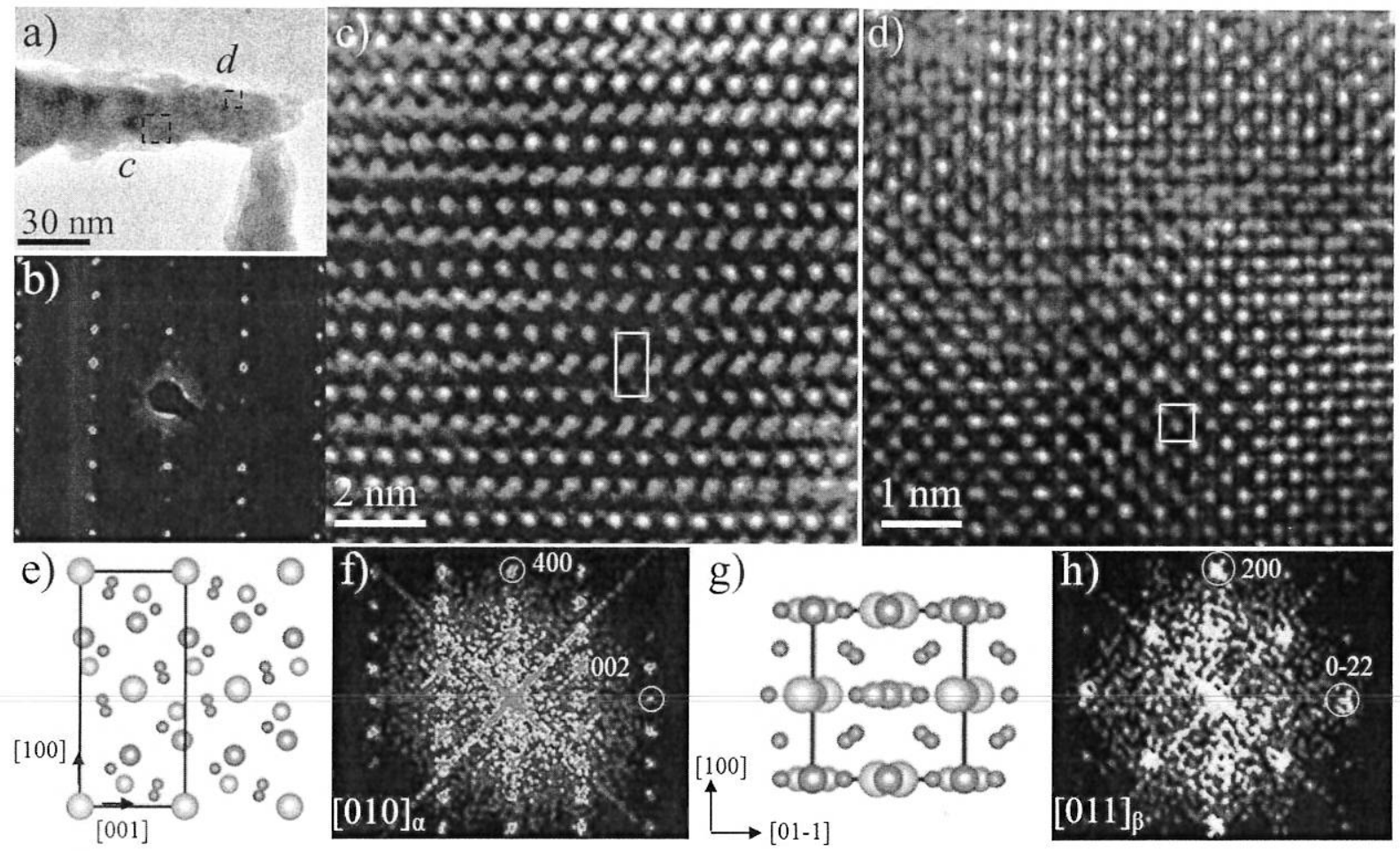

g)
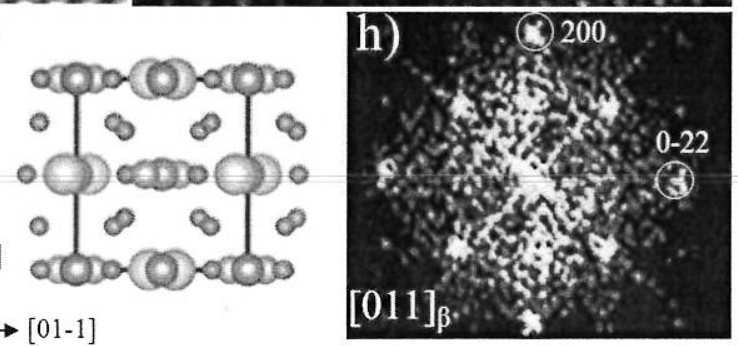

Figure 3. Microstructures of 2\# $\mathrm{LiFe}_{0.5} \mathrm{Mn}_{0.5} \mathrm{PO}_{4} @ \mathrm{C}$. (a) A TEM image showing a single 2\# LiFe ${ }_{0.5} \mathrm{Mn}_{0.5} \mathrm{PO}_{4} @ \mathrm{C}$ particle projected along the [010] direction, as indicated by the electron diffraction pattern in (b). (c, d) HRTEM images obtained from the local regions as marked by black boxes c and d in (a), respectively. (e, g) Structural models of $\alpha$ and $\beta$ phases, respectively, and the unit cells of these two phases are marked by black lines, corresponding to the white boxes in (c) and (d). O, P, Fe/Mn and Li ions are denoted as red, gray, brown and green spheres, respectively. (f, h) FFT patterns corresponding to the HRTEM images in (c) and (d), respectively. 

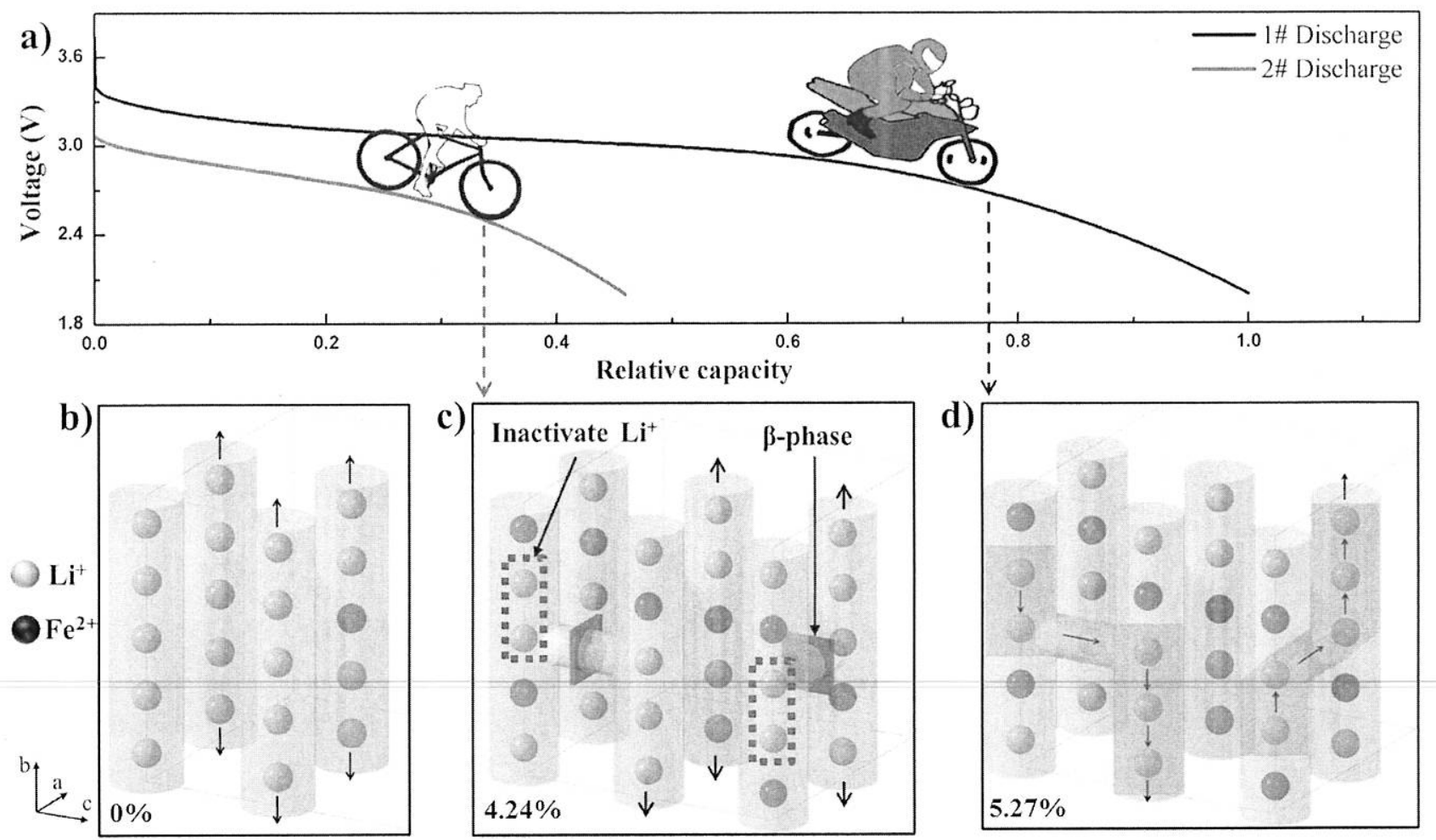

d)

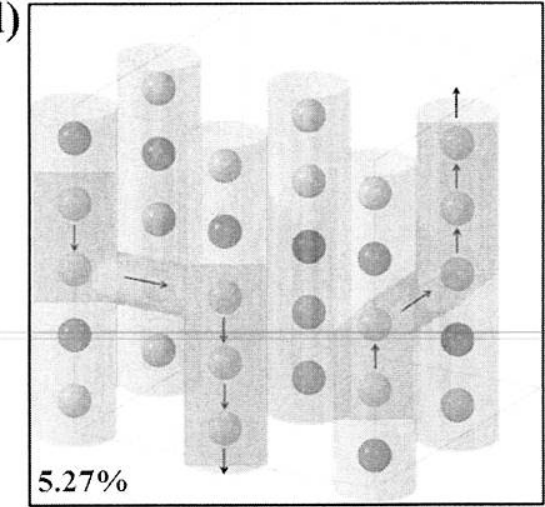

Figure 4. Origin of the different high-rate performance in $\mathrm{LiFe}_{0.5} \mathrm{Mn}_{0.5} \mathrm{PO}_{4}$ electrodes. (a) Capacity differences between 1\# and 2\# LiFe $0.5 \mathrm{Mn}_{0.5} \mathrm{PO}_{4} @ \mathrm{C}$ at a high current density. The total capacity of $1 \#$ sample was set to be 1. (b, c and d) Schematic illustration of $\mathrm{Li}^{+}$transport in $\mathrm{LiFe}_{0.5} \mathrm{Mn}_{0.5} \mathrm{PO}_{4} @ \mathrm{C}$ with different concentrations of $\mathrm{Fe}^{2+}-\mathrm{Li}^{+}$antisite defects. The data inserted in (b), (c) and (d) exhibit the different antisite concentrations. The red dotted box and the red baffle in (c) represent the inactive $\mathrm{Li}^{+}$and $\beta$-phase, respectively. 